
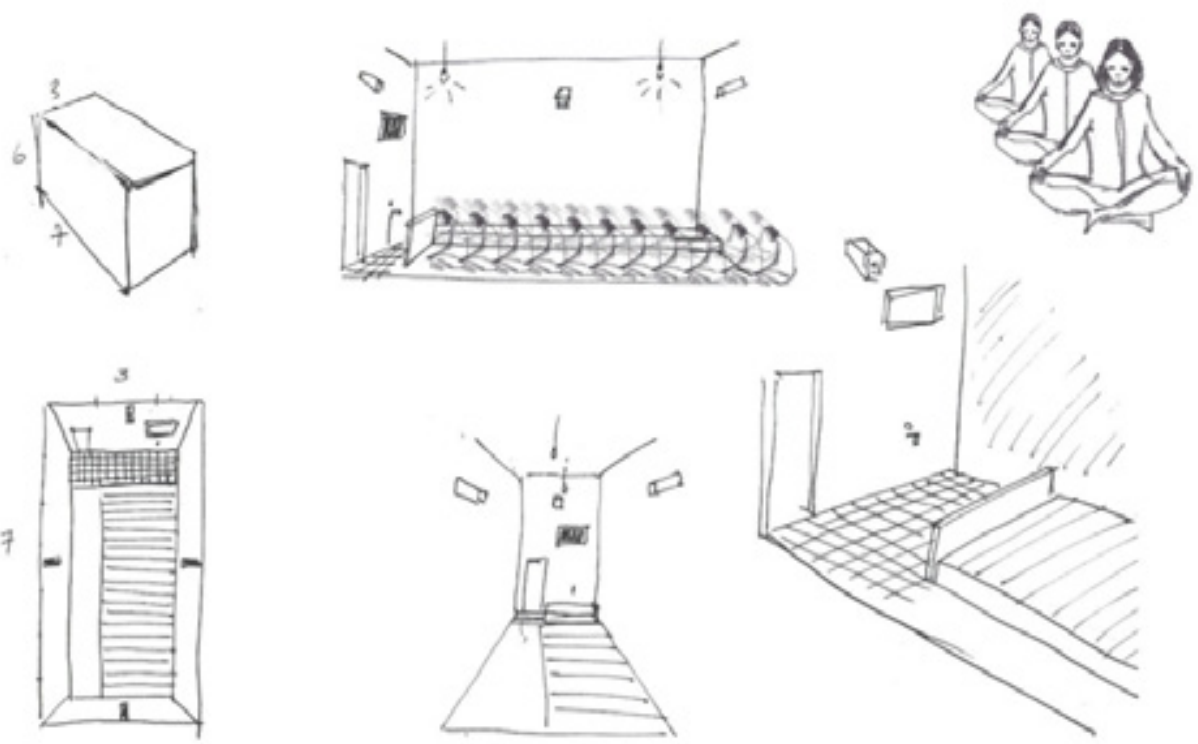

\title{
Preventative \\ Policing as \\ Community \\ Detention in \\ Northwest China
}

\begin{abstract}
A sketch recreating Gulbahar Jelilova's description of conditions inside a detention centre for women in Ürümchi. Illustration by Sofiya Voznaya / Coda Story. Reprinted with permission.
\end{abstract}

Darren BYLER

A preventative policing system in the Xinjiang Uyghur Autonomous Region has detained as many as 1.5 million Turkic Muslims deemed 'pre-terrorists' or 'extremists'. This essay shows how a counterinsurgency mode of militarism that emerged in the United States, Israel, and Europe, has been adapted as a 'Xinjiang mode' of community policing in China. It argues that the scale of detentions and the use of surveillance technology make the 'Xinjiang mode' of counterinsurgency unprecedented. ometime in May 2017 an ethnic Kazakh woman was detained in Ürümchi, the capital of the Xinjiang Uyghur Autonomous Region. Maybe this woman, a Chinese citizen, had travelled to Kazakhstan in the past or had relatives there. Maybe she had become part of a Quran study group on WeChat. It may not even be clear to her what 'micro-clue' of her potential 'extremism' resulted in her detention. In any case, once she was in custody a scan of her smartphone revealed that she had been in contact with 
an Uyghur woman in Kazakhstan. Eager to please her interrogators, whose priority was to capture 'returning terrorists', she placed a call to the woman in Almaty. She told this woman, Gulbahar Jelilova, that her mother, Gulbahar's partner in a shuttle trade business, was in the hospital and so she needed to travel across the border to Ürümchi to pick up the products she had ordered for export to Kazakhstan. Gulbahar was suspicious at first, because she had heard about the mass detention of Turkic Muslims that had begun earlier that year, but because she knew that her partner had a heart condition she thought that maybe the story of her illness was true. Since she was a Kazakhstani citizen who was born in Kazakhstan, she thought she had nothing to worry about despite her Uyghur ethnicity.

The morning after she arrived in Ürümchi, she found out how wrong she was. She said:

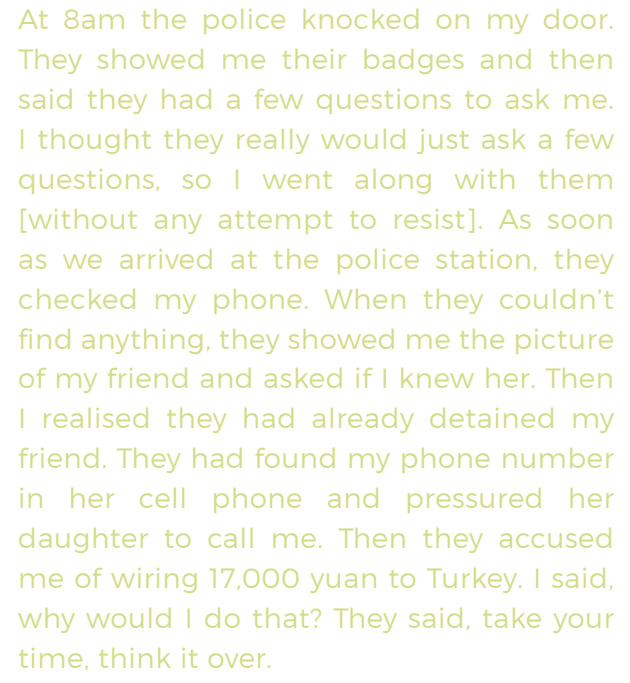

As it turned out, Gulbahar was given plenty of time to think about this. For the next year, three months, and 10 days she was held in a series of detention centres in Ürümchi. Conditions in these 'black site' holding centres, where detainees were investigated for potential connections to terrorism, were horrific. She and the more than 30 other Turkic Muslim women who shared her 14-square-metre cell were forced to take turns sleeping because there was not enough room for everyone to stretch out. The lights were never turned off. Their movements and speech were recorded by cameras and microphones.

Gulbahar, who spoke no Chinese, learned to say 'thank you' (谢谢) and 'here' (到) and to sing the Chinese national anthem 'The March of the Volunteers'. Every day she watched political speeches on TV monitors mounted high on the wall. This was the 'reeducation' (再 教育) component of her detention.

Her interrogators showed her a brand new Chinese ID card and made her memorise her new 18-digit citizenship number. They told her that she was not Gulbahar Jelilova, that she was a Chinese citizen now, and that she should confess her crimes.

Gulbahar had been caught up in the 'reeducation' system that explicitly targets Turkic Muslims. She was one of as many as 1.5 million people who had exhibited the 'early warning' (预警) signs of terrorism. This preventative policing system was built on models of counterinsurgency that emerged from the United States, Israel, and Europe, but adapted to 'Chinese characteristics' (中 国特色) that came from China's Maoist past. Together these models and technologies produced a coercive internment camp system which is implemented by an army of over one million non-Muslim civil servants and police (Byler 2018; see also Yi Xiaocuo's essay in the present issue). The project is supported by a comprehensive, AI-assisted biometric and digital surveillance system. The scale of detentions and the use of technology make the Chinese counterinsurgency unprecedented. It is the American war in Iraq without organised, weaponised insurgents and without mass killing; a Countering Violent Extremism (CVE) programme with purpose-built internment camps and state-run residential schools. It has adapted counterinsurgency to produce a new form of contemporary settler colonialism. 


\section{A Global Shift in
Counterinsurgency}

The experiences of Gulbahar Jelilova and others in her social network are indicative of a broader shift in policing and detention in northwest China and counterinsurgency around the world. As David Brophy (2019) has shown, since 2014 Chinese authorities have adopted forms of Islamophobia and counterinsurgent militarism that are similar to those of post-9/11 United States and other nations. As in the United States-led occupation of Iraq and Afghanistan in the mid-2000s, Chinese police have transformed Xinjiang into a space of exception-a counterinsurgent war zone, where active militants are thought to be hiding among the 'neutral population' (Harcourt 2018). In the American case, the only way to detect and uproot these terrorists-inhiding was through full-spectrum intelligence encompassing all inhabitants in the war theatre. Once knowledge dominance was achieved, the networks of the insurgency could be traced and fractured through processes of removal and isolation. The final step in counterinsurgency implementation was winning 'the hearts and minds' of a targeted population through humanitarian aid, infrastructure building, and job training. This, it was thought, would legitimate and solidify a 'regime change'.

A key element of the American experiment in Iraq and Afghanistan was the construction of a 'human terrain system'. At its height, this system employed 27 teams of social scientists, specialists on Islam and Arabic or Pashto and Dari, to enter people's homes and map out Iraqi and Afghani social relations as participantobservers, creating a database that would chart the communities and ideologies of the population (Kelly et al. 2010). This process, what the geographer Derek Gregory (2008) referred to as 'armed social work', was thought to produce a knowledge network that would anticipate insurgent threats. Ethnography aided in the targeted assaults necessary for the selective removal and internment of insurgent leaders in a network of camps. By 2008, Camp Bucca, the largest of these camps, had as many as 18,000 detainees-including Abu Bakr alBaghdadi, the future leader of the Islamic State.

Since 2016, a similar system has been put in place in Xinjiang (Mahmut 2019). Unlike in Afghanistan or Iraq, there is no organised, armed insurgency, yet Uyghurs and other Turkic Muslims have been targeted as 'preterrorists' in similar ways. Chinese authorities use many of the same 'enhanced interrogation' techniques used by the Bush administration. An important distinction however, is that the Chinese government pathologises nearly all forms of Turkic Islamic practice as expressions of mental illness, and strive to transform Muslims through psychiatric treatment, language education, political indoctrination, and coercive factory labour in an internment camp system much more extensive than camps in Iraq or Afghanistan (Grose 2019). In Xinjiang, the police are not attempting to produce political regime change, the institutions of the state are already fully within their grasp. Here there is something more. As in settler colonial systems around the world (Wolfe 2006), they are attempting to produce deep epistemic and social elimination by detaining and retraining the entire population. This is accomplished through increasingly restrictive nested systems of biometric and digital surveillance checkpoints-ending in the tight constraints of the camps and prisons themselves. All Uyghurs and other Turkic Muslims are detained to varying degrees in what can be described as the 'open air prisons' (sirttiki türme) of their communities.

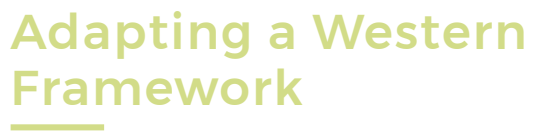

State media and policing theorists in China began to notice the shift in US militarism as early as 2007, when discussions of the 'Petraeus Doctrine' (彼得雷乌斯主义), the new counterinsurgency manual named for General 
David Petraeus, signalled a transformation of military science around the globe (Yang 2007). Over the next several years, scholars at elite police academies across China began to examine counterinsurgency theory, first as practiced by the US military and then the way it was adapted and technologically assisted in Israel ( $\mathrm{Lu}$ and $\mathrm{Cao} 2014$ ). In the space of less than a decade this new theoretical paradigm was adapted in practice in Xinjiang.

Much of the impetus behind this shift from academic research to policy implementation emerged from the tragic events of 2013 and 2014 in Beijing and Kunming. In the first of the two incidents a family of Uyghur attackers drove a vehicle into a crowd of tourists in Tiananmen Square on 28 October 2013; in the second, on 1 March 2014-an episode often referred to as 'China's 9/11'-Uyghur attackers killed dozens of Han travellers in the Kunming train station (Doyon 2018). Within a year, the new forms of policing that had been observed in Palestine, Afghanistan, and Iraq coalesced into a series of Chinese National Science Foundation policing theory projects, such as 'The Anti-Terrorism Model of Community Policing with Chinese Characteristics' (Lowe 2017).

One of the leaders of this new paradigm of Chinese policing, which stresses 'prevention' (预防) through 'pre-emptive strike' (先发制 人), is a young scholar from Shenyang named Cao Xuefei. Named to the project while still a $\mathrm{PhD}$ student in police science and antiterrorism at Charles Sturt University in Australia, Cao and a colleague named Lu Peng published an influential article on the way Israeli counterinsurgency theory should be used as an inspiration for counterterrorism in Xinjiang. As his thinking continued to evolve, Cao and another colleague translated a book called Policing Terrorism by CVE expert David Lowe (2017). Their award-winning Chinese translation of the book provided an 'empirical basis' from which to expand Chinese antiterrorism in relation to the Islamic State, which many suspected was connected to the Uyghur attacks in Beijing and Kunming. Lowe's book, which analysed the methods used by Islamic
State affiliates in Britain to 'radicalise and recruit people to their causes', also stressed 'critical' methods of gathering intelligence through surveillance and community informants.

In an article that was published in the summer of 2016, Chinese policing theorists $\mathrm{Ji}$ Yantao and Yin Wei (2016) began to describe the way this turn in policing could be adapted in a Chinese context by emphasising the need to move to prevention rather than 'passive reaction'(被动反应). Ji and Yin argued that this new form of policing should supplement the military-style 'intervention' (千预) and 'harsh punishment and suppression'(打击和严格的惩 罚) that had typified earlier 'Strike Hard' (严 厉打击) campaigns in Xinjiang. Yet, although they were suggesting a broader approach, they were careful to note that terrorism in China was rooted in social causes such as 'education, religion, ethnicity, and economic factors' and was 'not directly proportionate to police presence'(Ji and Yin 2016, 144). As per the Party position-which resonated with that of CVE advocates around the world-they claimed that Uyghurs were terrorist-prone because of their social and cultural systems, and failed to acknowledge the role of police brutality and colonisation. In any case, they argued for the key focus on anti-terrorism to shift to 'preemptive strikes' facilitated by civilian intelligence workers. At the core of this model was a term $\mathrm{Ji}$ and Yin repeated 58 times in the space of 12 pages: 'prevention' (预防).

From their perspective prevention encompasses three interlinked domains: 'strike prevention' (打击性预防), 'controlled prevention' (控制性预防), and 'protective prevention' (保护性预防). Strike prevention refers to the 'real-time control of key highrisk populations' ( $\mathrm{Ji}$ and Yin 2016, 150) such as people like Gulbahar: 'returning' (回流) terrorism suspects. Uyghurs that had lived abroad in Muslim-majority environments with open access to information, especially those for whom there was evidence linking them to other suspects, needed to be 'preemptively attacked'. Once the terrorism suspect was in custody, 
they are moved into 'controlled prevention'. In this domain, people for whom there are not enough clues or evidence of terrorist intent needed to be 'controlled'(控制) in order to reduce the possibility of them committing a crime and to eliminate the 'unfavourable' (不 利) aspects of their behaviour and thinking. The third form, protective prevention, refers to the prevention of potential terrorism through comprehensive intelligence gathering and intervention in the 'breeding and spreading'( 滋生和蔓延) of terrorist thought among the general population.

In a striking departure from non-Chinese counterinsurgency, all of this intelligence gathering was to be run through a shequ (社区), a term that refers to a state-directed neighbourhood watch unit in urban areas, or through village-level neighbourhood brigades (大队), the most grassroots forms of Partyfacilitated policing in China. In Xinjiang, a shequ is staffed by mostly Han Party members and police, but also employs Uyghur auxiliary police and mostly Han volunteer informants mobilised in the fight against terrorism through a weekly intelligence report quota system. Although Chinese community policing echoes the rhetoric of Euro-American counterterrorism, Ji and Yin argue that 'the people' (人民)must be pressured to report on their neighbours in order for the blind spots in the intelligence system to be filled. The way this community policing is accomplished is by watching the Muslim population for 75 signs of 'extremist' (极端主义) Islamic practice, ranging from mosque attendance and Quran study to the common greeting Asalaam Alaykum (Buckley 2018; Greer 2018). Special attention is focussed on unauthorised religious knowledge and practice, and relationships to other suspects (Hunervan 2019). Unlike non-Chinese counterinsurgencies, each state-run watch unit is supported by a People's Convenience Police Station which conducts 'seamless' ( 无㖓) surveillance of Muslims within their jurisdiction through video monitoring, digital media history searches, biometric tracking, and human surveillance at mandatory political activities (Zhang 2016).

At the time when Ji and Yin were writing their 2016 article, the 'reeducation camps' in Xinjiang had not yet been fully built and sweeping purges of Uyghur and Kazakh societies had not yet begun. Less than one year later, Gulbahar and 1.5 million other Turkic Muslims began to be pushed through these domains of 'prevention' and subjected to the accompanying forms of social elimination.

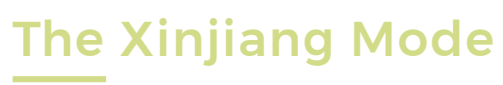

In November 2016, a new article appeared, written by Wang Ding and Shan Dan-theorists in a local Xinjiang police academy. The authors argued that the model of preventative policing that other policing theorists had proposed needed to be adapted in an explicit 'Xinjiang Mode'(新疆模式) that would not only transform religion, but also lead to a 'deep fusion' (深度融 合) of Turkic minorities into Chinese culture. They wrote that this new model would combine the full-spectrum intelligence 'war mode' (战 争模式) used by the US Army with a 'criminal mode' (犯罪模式) aimed at eradicating the root of terrorism-i.e. 'extremist' religious ideology. These two aspects of preventative policing would be brought together with a 'governance model'(治理模式) focussing on 'achieving a normal social order'(把社会秩序恢复到常态).

But what exactly was the 'normal' social order that Wang and Shan had in mind? As they put it: 'In the contemporary era there is no future for a religion without "culture"' (Wang and Shan 2016, 25). This is why they suggested there must be an acceleration of 'the deep fusion' of Chinese culture in Xinjiang, a process that they argued was in fact the 'most distinctive aspect of the Xinjiang Mode' of counterterrorism. They suggested that these adaptive approaches to counterterrorism were necessary due to the 
particular context of Xinjiang. Because it was a frontier region that was not yet fully settled by Han people, the local population generally lacked market integration. The deeper issue though remained religion, which, as Wang and Shan put it, was a 'personality problem' ( 个性问题). They wrote that the only way to deal with this was to be resolute in preventing people from being 'brainwashed' (洗脑) by a religion that had 'no culture' (没有文化). The implication was that because Turkic Muslims dangerously lacked 'culture', a term which referred explicitly to 'Chinese culture', there must be an acceleration of 'the deep fusion' of Chinese culture in Xinjiang.

Since Islam was so deeply integrated in the Xinjiang way of life, Wang and Shan argued that Turkic Muslims would need to unlearn nearly every aspect of their lives. The only way this could really be accomplished was if the entire population of non-Muslims in the region were bought into the process. They argued that people who possessed Chinese culture needed to 'occupy the positions of public opinion, the positions of cultural and social media platforms' throughout Xinjiang society (Wang and Shan 2016, 26). In writing this, they implied that Uyghur cultural leaders needed to be replaced through the full implementation of settler colonialism. Only then, would 'unstable factors' be 'nipped in the bud' (把各类不稳定因 素消灭在萌芽状态).

When Gulbahar Jelilova was lured back to Xinjiang as a suspected 'returning terrorist' in mid-2017, much of what these scholars had advocated for had been operationalised. Like hundreds of thousands of others, she was targeted with a 'strike prevention' arrest. From there she moved into 'controlled prevention' until she was eventually released into 'protective prevention'. Although she was found to be guilty of nothing other than being Uyghur and Muslim, the Xinjiang Mode of counterinsurgency radically upended her life.

\section{Communities as Prisons}

Those with the least amount of social power suffer the most in counterinsurgent war. According to the independent researchers at the organisation Iraq Body Count, there have been nearly 200,000 documented civilian deaths in Iraq since 2003 (IBC 2019). In Afghanistan, the US military and its allies have killed more civilians than the Taliban (Zucchino 2019). The cascading effect of these deaths and the widespread fragmentation of social life that has been produced through surveillance and removal in these spaces have produced tremendous forms of violence as social networks are broken and families are separated. The pain of counterterrorism is carried by those that remain into future generations and across communities (AlMohammad 2016).

As Arun Kundani and Ben Hayes (2018) have shown, in Europe and North America, Muslim communities have been asked to carry the brunt of the social violence that is tied to CVE programmes. Families, mosques, employers, and teachers are tasked with assessing their friends, relatives, and students as 'precriminals'. As in China, in Britain, extremism is 'pictured as a virus', and, counter to empirical evidence, religious ideology is assumed to be the primary cause of violence (Kundani and Hayes 2018). Instead of considering the role of structural violence, colonialism, and institutionalised Islamophobia, Muslimsespecially those who practiced their faith in public-are simply assumed to be potential terrorists.

Yet, despite all of these similarities, it is important to note that in liberal societies civil rights and free speech can produce a hedge against the implementation of mass extrajudicial detention and death. This was not the case in Iraq and Afghanistan. And it is not the case in China. As a local Xinjiang official put it recently, what is happening to Uyghurs is 'not 
about human rights violations. Uyghurs have no rights' (ITV 2019). This framing resonates with a common interpretation of human rights in China: human rights means the right of the majority Han people to be free from terrorism (Liu 2019). This in turn means that they have the right to be free from their fear of Turkic Muslims, the only population that is placed in the terrorism slot in the country.

The violence of the process that confronted Gulbahar Jelilova was significantly lessened by the relative privilege of her Kazakhstani citizenship. Without it, she would still be in some form of detention like hundreds of thousands of others. Racialised religious discrimination, intrusions of privacy, political censorship, disappearances, detention without due process, and a lack of personal and collective autonomy are institutionalised in Xinjiang. For most Uyghurs and Kazakhs there is no foreseeable end to their detention. Their communities themselves have become their prisons. 